Choking on carbon emissions from Greek academic paperwork

SIR-Selection processes for academic jobs are notoriously open to criticism, but in Greece they have the additional drawback of leaving a hefty carbon footprint.

Typically, selection committees for research institutes require applicants for a senior post to submit 11 paper copies of each of their publications (the Greeks' expansive view of publication sometimes includes texts of oral presentations) as well as of their birth certificate, national identity card (both sides), transcripts, translations of foreign degrees, and military and police reports.

In one recent case, the committee stopped the process to ask the minister of development to decide whether one worthy candidate should be excluded on the grounds that he had submitted his 66 publications on $11 \mathrm{CDs}$ instead of on paper.

What is the environmental impact of this nonsense? If candidates have an average of 50 publications each, a single copy of these, plus the additional paperwork required, can add up to a package of 1,000 pages per candidate. Making 11 copies of each, in an election with, say, four short-listed candidates, generates 44,000 sheets of paper. Excluding the cardboard boxes necessary to transport them, this works out to some $378 \mathrm{~kg}$ of $\mathrm{CO}_{2}$ per election (Solid Waste Management and Greenhouse Gases US Environmental Protection Agency, 1998). Almost all are later dumped in their original packaging, unopened.

University faculty positions are the worst, often being advertised at multiple levels. Candidates have to submit an identical package for each application level, copied to each voting member of the department. This can run to more than 100 complete sets of materials per candidate per position, contributing some 700 tonnes of greenhouse-gas emissions annually. Some of these cases end up being decided by the courts, so the pollution escalates.

It would help if the European Union would step in to curtail such wasteful and irresponsible practices.

Costas Synolakis Viterbi School of Engineering, University of Southern California, Los Angeles, California 90089-2531, USA

e-mail: costas@usc.edu

Spyros Foteinis Laboratory of Natural Hazards, Technical University of Crete, Chania, Greece

\section{Evolution pioneers: celebrating Lamarck at 200, Darwin 215}

\section{SIR - I take issue with the} contention that Erasmus Darwin, the grandfather of Charles, tackled evolution only in poetic terms, as implied by Dan Graur and colleagues in their insightful Book Review ('In retrospect: Lamarck's treatise at 200' Nature 460, 688-689; 2009).

Erasmus Darwin's most important contributions to evolutionary thought will be found in the very unpoetic prose of the first volume of his major medical and zoological treatise, Zoonomia, published in 1794.

Here, notably in Section 39, are discussions of deep time and the descent of all life from a single ancestor, bauplan homology among vertebrates, the analogy of artificial selection as a means of understanding descent with modification, and a brief but clear enunciation of the process of sexual selection.

One need only to look at the backlash against Erasmus Darwin's evolutionary ideas, in the savage political cartoons of James Gillray in 1798 and of others, to understand that - years before Lamarck made his contributions to evolutionary thought Erasmus Darwin was triggering strong reactions for promoting a transformist view of biodiversity.

This year is justly celebrating the history-altering contributions of Charles Darwin. But it is equally important to take stock of the critical intellectual steps before 1859 that made scientific and social acceptance of evolution possible.

Besides Erasmus Darwin and Jean Baptiste Lamarck, a host of other influential evolutionists, including Etienne Geoffroy Saint-Hilaire, Robert Chambers, Baden Powell, Herbert Spencer and Alfred Russel Wallace, deserve to be recognized (as well as read) for having laid a path to a modern view of descent with modification.

William E. Friedman Department of Ecology and Evolutionary Biology, University of Colorado, Boulder,

Colorado 80309, USA

e-mail:ned@colorado.edu

\section{Evolution pioneers: Lamarck's reputation saved by his zoology}

SIR - Work by Lamarck scholars over the past 20 years calls into question some of the assertions made by Dan Graur and his colleagues in their Book Review (Nature 460, 688-689; 2009).

For example, far from being universally scorned, Jean Baptiste Lamarck became known as 'the French Linnaeus' during the 1820s. Speaking at Lamarck's funeral in December 1829, Etienne Geoffroy Saint-Hilaire remarked that the last years of the old naturalist's life had been brightened by the awareness of how much his work was appreciated in Europe, and especially in France (see www. lamarck.cnrs.fr).

During the 1820s, scientific, medical and cultural magazines discussed Lamarck's work at length. Even conservative commentators, who disliked Lamarck's veiled atheism, acknowledged his eminence as the foremost invertebrate zoologist of Europe. In Britain, several naturalists - including Darwin's first scientific mentor in Edinburgh, Robert Edmond Grant - bought Lamarck's works and commented favourably on them. Lamarck's Natural History of Invertebrates (1815-22) became compulsory reading for hundreds of practitioners of the newly fashionable science, geology.

Furthermore, Lamarck can scarcely be said to be a deist, as your authors seem to argue. He did not deny that people had an idea of God, but as the only possible knowledge open to humankind was based on material substances and properties, nothing at all could be said of God. To Lamarck, nature had no purpose, no finality - in short, it was going nowhere.

Pietro Corsi University of Oxford, History Faculty, The Old Boys High School, George Street, Oxford OX12RL, UK e-mail: pietro.corsi@history.ox.ac.uk

\section{Religious belief and the history of science}

SIR - I am concerned that the survey responses expressed in Gene Russo's Prospects article 'Balancing belief and bioscience' are irrelevant to gauging the influence of religion on the development of scientists (Nature 460, 654; 2009).

Many of the great scientists renowned for developing entire scientific fields or theories were religious. For example, Gregor Mendel was a priest and Isaac Newton apparently spent as much time in religious contemplation as he did on calculus and physics. And Albert Einstein said: "Science without religion is lame, religion without science is blind."

As the works of most scientists today are not comparable with those of such luminaries, we should be cautious about using statistics on religious preference in judging scientific merit.

Scott Goode Department of Pathology, Baylor College of Medicine, S210 One Baylor Plaza, Houston, Texas 77030, USA

e-mail: sgoode@bcm.tmc.edu 